\title{
Calorimetric study on relaxation characteristics of epoxy polymers
}

\author{
O.S.Tulzhenkova, T.G.Sichkar, L.K.Yanchevsky, A.M.Shut \\ National Pedagogical Dragomanov University, \\ 9 Pirogova Str., 01601 Kyiv, Ukraine
}

Received March 14, 2017

\begin{abstract}
It is proposed a method for identifying the set of relaxation characteristics of glass epoxy polymers, which allows to separate the vitrification process from the glass overlay processes of different nature (post-curing). Using the example of bisphenol epoxy resin ED-16 a method of determining the optimal amount of curing agent is developed, which achieves the maximum degree of conversion of epoxy groups. The proposed method allows to determine the degree of conversion of the epoxy composition even at the final stages of the reaction and in the final compositions.
\end{abstract}

Keywords: epoxy polymers, activation energy, glass transition range, conversion level.

Предложен метод определения комплекса релаксационных характеристик стеклования эпоксидных полимеров, который позволяет отделить процесс стеклования от наложения процессов иной природы (доотверждения). На примере эпоксидной диановой смолы ЭД-16 разработан способ определения оптимального количества отвердителя, который обеспечивает достижение максимальной степени конверсии эпоксидных групп. Предложенный метод позволяет определять степень конверсии эпоксидной композиции даже на конечных стадиях реакции и в готовых композициях.

Релаксаційні характеристики епоксидних полімерів за даними калориметричних досліджень. О.С.Тульженкова, Т.Г.Січкар, Л.К.Янчевський, А.М.Шут.

Запропоновано метод визначення комплексу релаксаційних характеристик склування епоксидних полімерів, який дозволяє відокремити процес склування від накладення процесів іншої природи (доотвердження). На прикладі епоксидної діанової смоли Ед-16 розроблено спосіб визначення оптимальної кількості отверджувача, який забезпечує досягнення максимального ступеня конверсії епоксидних груп. Запропонований метод дозволяє визначати ступінь конверсії епоксидної композиції навіть на кінцевих стадіях реакції і в готових композиціях.

\section{Introduction}

Traditionally, relaxation characteristics of polymers are determined by method of relaxation spectrometry proposed by G.M.Bartenev [1-3]. In our work it is justified the use of calorimetric method as a more informative express method for determining the complex of relaxation characteristics exactly for glass transition [4-6].

Investigation of the glass transition relaxation characteristics (activation energy $U_{\alpha}$ and pre-exponential factor $B_{\alpha}$ ) of epoxy polymers with temperature - frequency measurements $[1,2]$ demonstrates the sufficiently high dependence of activation energy upon temperature and accordingly the low value of pre-exponential factor.

Such state witnesses a complex character of the epoxy polymers glass transition and needs the separate study of it's peculiarities. Firstly, difficulties can arise because of stoichiometrical misbalance of the oligomer and curing agent when unresolved (excess) reactionable component groups exist. In this case the resulting glass transi- 


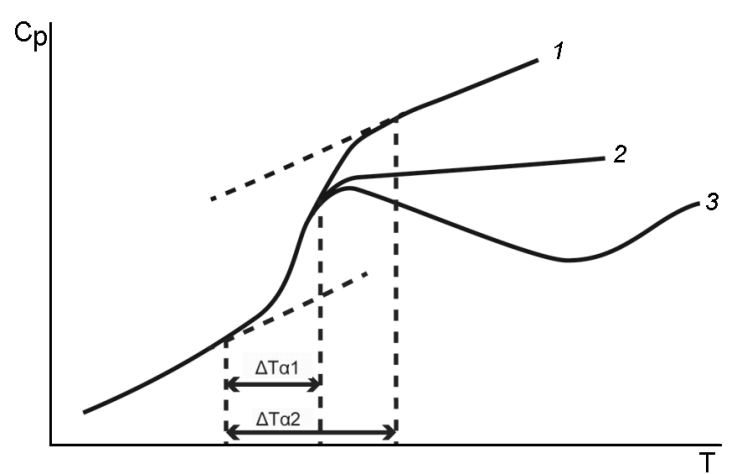

Fig. 1. Temperature dependences of specific heat characteristic glass transition range of epoxy polymers: 1 - fully cured composition; 2 - appearance of exothermic peak of after-curing process; 3 - result of imposing peak of after-curing process on process of glass transition. $\Delta T \alpha 1-$ glass transition interval that corresponds to fully cured composition; $\Delta T \alpha 2$ - spaced glass transition is observed as a result of the imposition of aftercuring process.

tion process consists of different parts depending of cross-linking level and hence glass transition temperature. Opposite situation appears when the glass transition overlaps with different nature processes, particularly, such as curing process [7]. Realization of these processes with repeatively heating provokes an after-curing peak appearance, which overlaps with a jump of heat capacity in the glass transition process on the curve of heat capacity dependence upon temperature (Fig. 1).

Study of the epoxy polymer glass transition process and using the calorimetric method of experimental relaxation characteristics complex determination for the glass transition process is the aim of this work.

\section{Theory and experimental results}

In the first case the processes overlapping makes temperature range of the glass transition wider, but in the second case, it makes that range shorter. So, it should be considered the experimental sensitives to such difficulties. Thus it is expedient to use for the glass transition characteristics complex determination the method based on experimentally obtained temperature range [4-7].

This complex comprises: activation energy $U_{\alpha}$, kinetic unit self oscillation frequency $B_{\alpha}$, glass transition temperature $T_{\alpha}$, glass transition cooperative level $w$, seg-

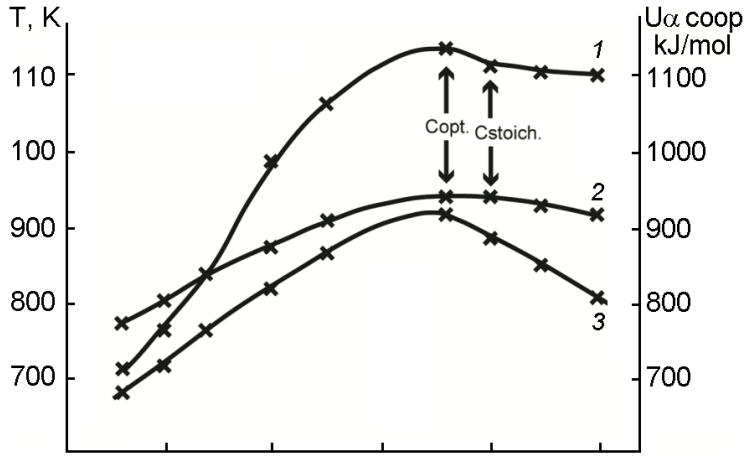

Fig. 2. Dependences of glass transition temperature (1) and edge components of activation energy $(2,3)$ of $\operatorname{ED}-16+\operatorname{MA}\left(C_{x}\right)+$ DA(0.5) composition upon amount of curing agent $C_{x}$.

ment cooperative activation energy $U_{\alpha \text { coop }}$ for edge components of glass transition (1, 2 indexes) and the most probable glass transition temperature (without index). Listed characteristics were obtained with equations from [3-5]:

$$
\begin{gathered}
B_{\alpha}=T_{\alpha} \cdot 1.6 \cdot 10^{-14}, \\
\Delta T_{\alpha 1}=2\left(\frac{\Delta_{\alpha 1}}{2} \ln \frac{\Delta T_{\alpha 1}}{2 q B_{\alpha 1}}-T_{1}\right), \\
\Delta T_{\alpha 2}=2\left(T_{2}-\frac{\Delta T_{\alpha 2}}{2} \ln \frac{\Delta T_{\alpha 2}}{2 q B_{\alpha 2}}\right), \\
U_{\alpha}=\frac{2 R T_{\alpha}^{2}}{\Delta T_{2}}, \\
U_{\alpha c o o p}=\frac{4 v_{e q} R T_{\alpha}^{2}}{q}, \\
\omega=\frac{2 \Delta T_{\alpha} v_{e q}}{q}, \\
T_{\alpha}=\frac{\Delta T_{\alpha} \ln \frac{\Delta T_{\alpha}}{2 q B_{\alpha}},}{2}
\end{gathered}
$$

where $T_{1}$ - temperature of glass transition jump begining, $T_{2}$ - temperature of glass transition jump end, $v_{e q}$ - equal frequency, $9 \cdot 10^{-3} \mathrm{~Hz}$ (frequency equal to current temperature scanning speed).

The object of the study was epoxy dianous resin ED-16. Maleic anhydrith (MA) was used as a curing agent. Diaminanilin was used as a modifier in ratio of 0.5 mass 
Table 1. Values of glass transition relaxation characteristics complex of ED-16 (100) $+\mathrm{MA}\left(C_{x}\right)+$ $\mathrm{DA}(0,5)$ based system

\begin{tabular}{|c|c|c|c|c|c|c|c|c|c||}
\hline $\begin{array}{c}C_{x}, \operatorname{mass} \\
\mathrm{parts}\end{array}$ & $\begin{array}{c}B_{\alpha 1} \cdot 10^{12}, \\
\mathrm{~s}\end{array}$ & $\begin{array}{c}B_{\alpha 2} \cdot 10^{12} \\
\mathrm{~s}\end{array}$ & $\begin{array}{c}U_{\alpha 1}, \\
\mathrm{~kJ} / \mathrm{mol}\end{array}$ & $\begin{array}{c}U_{\alpha 2}, \\
\mathrm{~kJ} / \mathrm{mol}\end{array}$ & $\begin{array}{c}U_{\alpha}, \\
\mathrm{kJ} / \mathrm{mol}\end{array}$ & $\omega_{1}$ & $\omega_{2}$ & $\begin{array}{c}U_{\alpha} \operatorname{coop} 1 \\
\mathrm{~kJ} / \mathrm{mol}\end{array}$ & $\begin{array}{c}U_{\alpha \text { coop } 2}, \\
\mathrm{~kJ} / \mathrm{mol}\end{array}$ \\
\hline \hline 23,5 & 5,4 & 5,7 & 87 & 93 & 90 & 8.0 & 8.4 & 690 & 780 \\
25 & 5.5 & 5.7 & 89 & 94 & 91 & 8.1 & 8.4 & 718 & 790 \\
27.5 & 5.6 & 5.8 & 92 & 94 & 93 & 8.3 & 8.6 & 767 & 804 \\
30 & 5.8 & 6.0 & 95 & 98 & 97 & 8.6 & 8.9 & 819 & 868 \\
33 & 6.0 & 6.1 & 97 & 100 & 99 & 8.8 & 9.0 & 853 & 900 \\
38 & 6.1 & 6.2 & 100 & 101 & 100 & 9.0 & 9.1 & 902 & 921 \\
42.5 & 6.0 & 6.2 & 98 & 101 & 100 & 8.8 & 9.1 & 863 & 920 \\
45 & 5.9 & 6.2 & 94 & 101 & 99 & 8.7 & 9.1 & 823 & 917 \\
\hline
\end{tabular}

Table 2. Experimental and calculated characteristics of glass transition range and conversion level characteristics of UP-643 + IMTHPA system

\begin{tabular}{|c|c|c|c|c|c|c|}
\hline Mode & $T_{1}, \mathrm{~K}$ & $\Delta T_{\text {calc }}, \mathrm{K}$ & $T_{\alpha 1 \text { calc }}, \mathrm{K}$ & $\Delta T_{\text {calc }}-\Delta T_{\text {exp }}, \mathrm{K}$ & $\alpha, \%$ & $K, \%$ \\
\hline 1. Not cured & 250 & 16.6 & 258 & 0.5 & 0 & - \\
\hline 2. $353 \mathrm{~K}, 0.25 \mathrm{~h}$ & 252 & 16.7 & 260 & 4.0 & 2 & - \\
\hline $3.353 \mathrm{~K}, 0.5 \mathrm{~h}$ & 260 & 17.2 & 269 & 5.0 & 6 & - \\
\hline 4. $353 \mathrm{~K}, 1.5 \mathrm{~h}$. & 268 & 17.7 & 277 & 5.5 & 11 & - \\
\hline $5.353 \mathrm{~K}, 2.75 \mathrm{~h}$. & 284 & 18.8 & 293 & 6.0 & 4 & - \\
\hline $6.353 \mathrm{~K}, 3.25 \mathrm{~h}$. & 298 & 19.7 & 308 & 6.6 & 62 & - \\
\hline 7. $393 \mathrm{~K}, 1 \mathrm{~h}$. & 313 & 20.6 & 323 & 7.0 & 75 & - \\
\hline 8. $353 \mathrm{~K}, 5 \mathrm{~h}$. & 340 & 22.3 & 351 & 7.5 & 81 & - \\
\hline 9. $353 \mathrm{~K}, 3 \mathrm{~h} .+373 \mathrm{~K}, 1 \mathrm{~h}$. & 342 & 22.5 & 353 & 10.5 & 90 & 53 \\
\hline 10. $353 \mathrm{~K}, 10 \mathrm{~h}$. & 348 & 22.9 & 360 & 8.9 & 92 & 61 \\
\hline 11. $373 \mathrm{~K}, 3 \mathrm{~h}$. & 360 & 23.6 & 372 & 6.1 & - & 74 \\
\hline 12. $393 \mathrm{~K}, 6 \mathrm{~h}$. & 374 & 24.5 & 386 & 5.5 & - & 78 \\
\hline 13. $473 \mathrm{~K}, 1 \mathrm{~h}$. & 378 & 24.8 & 390 & 5.0 & - & 80 \\
\hline 14. $393 \mathrm{~K}, 3$ h. $+453 \mathrm{~K}, 2$ h. & 381 & 25 & 395 & 4.5 & - & 83 \\
\hline 15. $473 \mathrm{~K}, 2 \mathrm{~h}$. & 383 & 25.1 & 395 & 4.0 & - & 84 \\
\hline 16. $473 \mathrm{~K}, 3 \mathrm{~h}$. & 384 & 25.1 & 396 & 3.0 & - & 86 \\
\hline 17. $473 \mathrm{~K}, 6 \mathrm{~h}$. & 385 & 25.2 & 397 & 0.5 & - & 98 \\
\hline 18. $473 \mathrm{~K}, 12 \mathrm{~h}$. & 385 & 25.2 & 397 & 0.5 & - & 98 \\
\hline
\end{tabular}

parts of the modifier to 100 mass parts of ED-16.

Dependence of glass transition temperature upon amount of curing agent presented in Fig. 2. Also respective dependence of $U_{\alpha \text { coop } 1,2}$ is presented there. The relaxation characteristics complex of listed systems presented in Table 1 obtained from equations (1)-(7). $T_{1}$ and $T_{2}$ were experimentally obtained from the calorimetric curves.

Investigation on dependence of compositions properties upon curing agent amount was performed to develop a method for determining the curing agent optimal amount. The optimal amount of the curing agent provides the reaching of maximum conversion level [8] during curing mode at $473 \mathrm{~K}$ for $12 \mathrm{~h}$. Different temperature and time modes allows the obtaining of samples with excess or shortage of appropriate reactive groups, e. a. the samples of systems with different content of segments for future studying. 
Table 3. Relaxation characteristics of UP-643 + IMTHPA system

\begin{tabular}{|c|c|c|c|c|}
\hline Mode & $U_{\alpha}, \mathrm{kJ} / \mathrm{mol}$ & $B_{\alpha} \cdot 10^{12}, \mathrm{~s}$ & $\omega$ & $U_{\alpha \text { coop }}, \mathrm{kJ} / \mathrm{mol}$ \\
\hline 1. Not cured & 66.6 & 4.1 & 6.2 & 413 \\
\hline 2. $353 \mathrm{~K}, 0.25 \mathrm{~h}$. & 67.2 & 4.2 & 6.2 & 417 \\
\hline 3. $353 \mathrm{~K}, 0,5 \mathrm{~h}$. & 69.8 & 4.3 & 6.4 & 447 \\
\hline 4. $353 \mathrm{~K}, 1.5 \mathrm{~h}$. & 72.0 & 4.4 & 6.6 & 475 \\
\hline $5.353 \mathrm{~K}, 2.75 \mathrm{~h}$. & 76.0 & 4.7 & 7.0 & 432 \\
\hline 6. $353 \mathrm{~K}, 3.25 \mathrm{~h}$. & 80.2 & 4.9 & 7.3 & 585 \\
\hline 7. $393 \mathrm{~K}, 1 \mathrm{~h}$. & 84.0 & 5.2 & 7.7 & 647 \\
\hline 8. $353 \mathrm{~K}, 5 \mathrm{~h}$ & 91.6 & 5.6 & 8.3 & 760 \\
\hline 9. $353 \mathrm{~K}, 3$ h. $+373 \mathrm{~K}$ & $1 \mathrm{~h}$. & 92.2 & 5.6 & 8.4 \\
\hline 10. $353 \mathrm{~K}, 10 \mathrm{~h}$ & 94.2 & 5.8 & 8.5 & 800 \\
\hline 11. $373 \mathrm{~K}, 3 \mathrm{~h}$. & 97.4 & 6.0 & 8.8 & 857 \\
\hline 12. $393 \mathrm{~K}, 6 \mathrm{~h}$. & 100 & 6.2 & 9.1 & 919 \\
\hline 13. $473 \mathrm{~K}, 1 \mathrm{~h}$. & 102 & 6.2 & 9.2 & 938 \\
\hline 14. $393 \mathrm{~K}, 3$ h. $+453 \mathrm{~K}, 2 \mathrm{~h}$. & 103 & 6.3 & 9.3 & 958 \\
\hline 15. $473 \mathrm{~K}, 2 \mathrm{~h}$ & 104 & 6.3 & 9.3 & 967 \\
\hline 16. $473 \mathrm{~K}, 3 \mathrm{~h}$. & 104 & 6.3 & 9.4 & 978 \\
\hline 17. $473 \mathrm{~K}, 6 \mathrm{~h}$. & 104 & 6.4 & 9.4 & 978 \\
\hline 18. $473 \mathrm{~K}, 12 \mathrm{~h}$. & 104 & 6.4 & 9.4 & 978 \\
\hline
\end{tabular}

The second group of samples, in which the object of research was the system of UP-643+IMTHPA (isomethyltetrahydrophthalic anhydride), was obtained with the optimal ratio of resin and curing agent, but with the different curing modes. This allows the obtaining of the samples with different solidification level and different intensity of after-curing process under repeated heating. The experimentally obtained and calculated characteristics of the glass transition range, the values of conversion level and calculation factor $K$ are presented in Table 2.

Table 3 presents the relaxation characteristics complex of respective samples, calculated using equations (1)-(7) and data of Table 2.

It was obtained two groups of the samples. One of them is related to system with slow change of amount of uninvolved reactive groups with no involving opportunity under repeated heating, e. a. exfoliation of the system depending on segment contents is modeled. The second group of the samples is related to system with optimized quantity of reactive groups, but with change of after-curing process, different intensity of the after-curing processes and overlapping with the glass transition process is modeled. We can consider that such point of view allow us to detach the glass transition process and its components, neglecting the overlapping of other processes.

\section{Discussion}

Table 1 and Fig. 2 data allow the obtaining of the optimal ratio of resin to curing agent using $T_{\alpha}$ behavior or changes of $U_{\alpha \text { coop 1,2 }}$ Traditional methods allow to do this when $T_{\alpha}$ reaches the maximum (curve 1 in Fig. 1). In suggested method the optimality responds to the maximum approaching $\mathrm{U}_{\alpha \text { coop } 1}$ to $\mathrm{U}_{\alpha \text { coop } 2}$ (curves 2, 3 in Fig. 2) and reaching them to the maximum. Equality of $C_{x}$ in the both methods justifies applicability of suggested method. It is necessary to note that difference between $C_{o p t}$ and $C_{\text {stoich }}$ is considerably big (38 and 40 mass parts, respectively). This tells about experimental correction of value $C_{x}$ for obtaining high quality products made of epoxy resins. Suggested method provides more information and allows observing of dynamics of system segment contents heterogeneity change. And even more, it is shows unattainability of the full system homogeneity even with $C_{\text {opt }}$.

About second group of the samples UP$643+$ IMTHPA we can mention that analysis of the obtained results allow us to suggest 
the calorimetric method for epoxy compositions conversion level estimation.

In Table 2 the conversion level $\alpha$ and $K$ factor are compared. The conversion level $\alpha$ was obtained with traditional method using the following equation:

$$
\alpha=\frac{\Delta H_{0}-\Delta H}{\Delta H_{0}} \cdot 100 \%,
$$

where $\Delta H$ - enthalpy of after-curing process of sample; $\Delta H_{0}$ - enthalpy of resin and curing agent mixture, taken at once after mixing. $K$ factor can by derivate using equation:

$$
K=\frac{\Delta T_{\mathrm{exp}}}{\Delta T_{\text {calc }}} \cdot 100 \% .
$$

This equation is based on fact that $\Delta T_{\text {exp }}$ is deformed by overlapping of the after-curing peak and $\Delta T_{\text {calc }}$ is not. Thus more intensive after-curing peak produces the smaller value of $\Delta T_{\text {exp }}$. That is why the value of $K$ factor corresponds to changes of the conversion level. It is evident that $\alpha$ and $K$ factors have different destinations. In the beginning $\alpha$ can quite efficiently describe the conversion level, but $K$ factor can efficiently describe the ending of this process. It is practically important, as estimation of conversion level in the ending phase allow evaluating the completion level of the reaction, quality of the compiled products made of epoxy resins. Introduction and using of calculated $K$ factor is more important because of any method among the methods of epoxy polymers curing process kinetics investigation, which are widely used in techniques (ultrasonic, infra-red spectrometry, titration of detached samples) can not allow to evaluate the conversion level in the ending phases of reaction.

\section{Conclusions}

Thus, the new method has been suggested for determination of the complex of epoxy polymers glass transition relaxation characteristics. This method can free the glass transition from overlapping with processes of other nature. Also it can help to obtain the components of the complex glass transition process in heterogeneous system with segment contents.

Suggested calorimetric method is based on experimental investigation of epoxy polymer heat capacity. This is universal method, as it allows to:

- determine the relaxation characteristics (activation energy $U_{\alpha}$ and pre-exponential factor $B_{\alpha}$ );

- investigate the samples of completed production and control the curing process from the beginning to the end;

- determine the optimal ratio of resin to curing agent in epoxy composition;

- obtain the conversion level of epoxy composition in the ending phases of reaction and in completed products.

\section{References}

1. N.I.Shut, G.M.Bartenev, M.V.Lazorenko, T.G.Sichkar, Acta Polimerica, 42, 384 (1991). http://dx.doi.org/10.1002/actp.1991.010420 810

2. G.M.Bartenev, N.I.Shut, V.P.Dushchenko, T.G.Sichkar, Vysokomolek. Soyedin., Ser.A, 28, 627 (1986).

3. A.I.Slutsker, Yu.I.Polikarpov, K.V.Vasileva, Fizika Tverdogo Tela, 44, 1529 (2002).

4. L.K.Yanchevski, V.V.Levandovski, Acta Polimerica, 44, 29 (1993). http://dx.doi.org/ 10.1002/actp.1993.010440104

5. T.G.Sichkar, L.K.Yanchevsky, O.V.Gorshunov, M.I.Shut, Iss. Chem. and Chem. Techn., 1, 228 (2004).

6. M.I.Shut, M.A.Rokitskiy, A.M.Shut, G.V.Rokitskaya, Functional Materials, 20, 221 (2013). http://dx.doi.org/10.15407/fm20.02.221

7. N.I.Shut, T.G.Sichkar, A.P.Dyn, V.P.Dushchenko, Acta Polimerica, 38, 446 (1987). http://dx.doi.org/10.1002/actp.1987.010380 709

8. M.Urbaniak, Polimery, 56, 240 (2011). 